\title{
Sociolinguistic Protests for Decolonial Future Making: Toward Centering Languaging in the "Streets"
}

\author{
Eunjeong Lee \\ Assistant Professor of English, University of Houston, Houston, TX, USA \\ elee33@central.uh.edu \\ Sinfree Makoni \\ Professor of Applied Linguistics and African Studies, Pennsylvania State \\ University, University Park, Pennsylvania, USA \\ sinfreemakoni@hotmail.com
}

\begin{abstract}
In scholarly discussions on "language" and "diversity," much critique has been offered as to how research on languaging is implicated in perpetuating coloniality and pursuing decolonial options, including the white-gaze understanding and approach to the term, "diversity" (Heller and McElhinny 2017; Mignolo 2009; Rosa and Flores 2017; Walcott 2018). Extending these discussions, this article calls for centering languaging in the "streets" as an important way for sociolinguistics to contribute to building decolonial futures. We see "streets" as an embodied, dynamic space, organized by the goal of decolonial future making, layered with conflicting struggles, discourses, and historicities. Examining languaging in the "streets" can highlight how those oppressed by various colonial conceptualizations and ongoing coloniality work toward social justice and transformation in and beyond classrooms. We suggest three important considerations in sociolinguistic research on languaging in the "streets," and conclude by emphasizing the importance of reflexivity of individual researchers and the field as a whole.
\end{abstract}

\section{Keywords}

sociolinguistic protest - decoloniality - social activism - languaging 


\section{Introduction}

In this article, we discuss how sociolinguistic research can contribute to (re) imagining and building decolonial futures. We pay specific attention to how the research on language and society can be mobilized when working toward decolonial futures that are more just, equitable, and humanizing. The issue is particularly important, given the current sociopolitical climate. As we are writing in 2020, the US - the context in which we are situated — has witnessed the violence inflicted by ongoing white supremacy, often as a response to the now-former President Trump's harmful rhetoric on Black, Indigenous, Latinx, Asian, Muslim, refugees, and migrants-both documented and undocumented. The COVID-19 pandemic has magnified socioeconomic and inequities and inequalities, as disproportionately experienced by Black and Latinx communities. In the wake of the increasing threat of public health concerns due to the COVID-19 pandemic and incessant police brutality on Black communities, the project of examining our research - the tools we use, the historicities in which our work is situated, and the impact it has on minoritized communities - carry heightened significance. In the backdrop of the sociopolitical climate that continues to witness the white supremacy's incessant violence upon Black, Indigenous, Latinx, Asian, and otherwise racialized communities, how can we as engaged activist scholars concerned about languaging, ${ }^{1}$ broadly speaking, contribute to reimagining decolonial and democratic futures through our work? More specifically, how can our work address the current social challenges, including social inequities and inequalities? We see this reflexive interrogation as one essential step in working towards creating just and decolonial futures.

To this end, we focus on the issues that the contemporary frameworks for research on languaging must address to challenge the structural inequities and inequalities and discuss ways to reimagine a future in which different ways of being, knowing, and doing language and literacies by our racialized and language-minoritized students and communities can be sustained and thrive. As

1 Bagga-Gupta (2004), Canagarajah (2013), García and Li (2014) and countless other scholars that we cite in this article have been arguing for the need to understand language beyond a conventional formulation as rooted in the structuralist view and emphasize the practice of language, or "doing" of language in recognizing its complex, dynamic, and emergent nature as also entangled in the current era of increased mobility. Following their approach to language as practices and processes, we use the term, languaging, in this article, encompassing multiple ways of doing language and literacies. Yet, because the term, languaging, carries its history as an academic concept, we use "language and literacy" when referring to previous research conducted under such terms to avoid confusion. 
Monica Heller and Bonnie McElhinny (2017) emphasize in their discussion of the history of discrimination, violence, and harm, as intersected with European colonialism and capitalism, "language is not peripheral" (xv) to the historical and ongoing violence on racialized and language-minoritized people. In this regard, we argue that theories of languaging should be informed by, and able to account for, sociolinguistics of the "streets" - more specifically, the study of languaging as involved in the push-pull between those striving to maintain the colonial social order that centers and serves white interests only, and those who work to dismantle this order. Following Santos (2016), we see "streets" as characterized by struggles, and by extension, as a space of activism and protests that fight for justice and equity where a range of activities and languaging dynamically constructs the temporalities and space, as well as intersubjective positionings, which in turn shapes the languaging. ${ }^{2}$ In this regard, we emphasize the importance of analyzing knowledges produced during struggles of the oppressed.

While our discussion is conceptual in its nature, we draw insights from empirical work in fields of study as broadly conceived as relevant to languaging, particularly those that concern the politics of (language) difference, engaging with scholarships from critical applied linguistics, literacy studies, education, and decolonial studies. We situate this constellation of scholarly discussions that aim to pursue and sustain alternative ways to know, view, and live in and with language away from the European and U.S. settler colonial logic, intersected with the transnational neoliberalist mode of thought, in seeking a decolonial option (Mignolo 2009; Quijano 2007). In advancing our argument to engage more explicitly with the "streets," we speak from our own locale and positionalities - both immigrant, multilingual, and transnational female and male scholars of color with ties to South Korea and Zimbabwe, Ghana, South Africa, and Kenya, respectively and situated in the US higher education institutions. While we acknowledge that our positionalities do not necessarily determine epistemological and ontological orientations, it is important to note that we cannot escape from such positionalities and the intersectional workings of different elements and layers that constitute our identities.

The article first discusses how frameworks of language and literacy are implicated in the "decolonial imagination" (Savaransky 2017), as modes of thought with particular assumptions that view certain social practices, relations, and bodies as "normal" and "legitimate." The terms of reading and

2 We are aware of a potential critique that such a claim may be based on an ableist perspective. We approach these terms, particularly protests and activism, acknowledging that they can take place in multiple modalities, platforms, and locales, and are not monolithic and uniform. 
imagining "now" and "future," and many other ways that organize the world, therefore remains responsible for many injustices and harms inflicted upon those bodies these frameworks often marginalize. Yet, as Mary Bucholtz (2018) importantly notes, our work often remains at "raising awareness" rather than dismantling the structure that (re)produces the injustices. In this regard, we argue that in order to realize the transformative potential of our "sociolinguistic activism" (Bucholtz 2018: 350), we need to better understand different spaces where "decolonial imagination" is happening-thereby sociolinguistics of the "streets." We pose that this shift of where we examine then requires fundamental changes in both our conceptualization of legitimate knowledge and how we approach such knowledge. More specifically, we discuss this shift in terms of (1) where/how we attend to languaging as part of the work that aims at social change and transformation, (2) whose voice and knowledge the research views as legitimate, and (3) how we stand in these spaces and from what positioning, in relation to our research participants and communities.

\section{Language, Literacy, and Diversity as a Product of the White Gaze}

As decades of research on languaging has shown, a theory of language has been constructed within the colonial matrix of power (Heller and McElhinny 2017; Makoni 1998; Makoni and Pennycook 2007; Patel 2016; Rosa and Flores 2017). Understood as part of a legacy of European nation-state building, and the abiding legacy of Enlightenment of the 18th century language is recognized as a marker of one's ethnic identity, buttressing the pervasive monolingual notion of one nation, one language, and one identity. The connection between language, identity, and nation-state that was forged out of this geopolitical backdrop also works to racialize, and therefore, oppress linguistic others. Jonathan Rosa and Nelson Flores (2017) find the linkage between language and race as a byproduct of colonial logic, ultimately shaping raciolinguistic ideologies through which one's language use is always understood and perceived through the white gaze. As a framework that centers and valorizes whiteness, the white gaze then works to shape and guide ways to understand, organize, and approach different bodies and their ways of being, doing, and knowing. The white-centered view even applies to the way the term, "diversity," has emerged and been used. Seemingly innocuous, the term "diversity" has been criticized due to how its emergence and usage works to erase different differences and the racialized nature of the way differences are assigned and approached. Rinaldo Walcott (2018), for instance, illuminates how the term 
erases particularity of Black struggles, while reproducing anti-Black racism. Walcott (2018: 9o) crucially notes:

The work of diversity can often obscure anti blackness and the impenetrable structures that continually produce Black peoples as out of place, as things, and as non-human. Similarly, the turn to [people of color] POC as a common denominator for non-white people... is an obscuring gesture too. . . By so doing, POC politics often assumes that one-size-fits-all for addressing issues of racism, especially in the diversity policies of large institutions. Such logics easily reproduce antiblack racism.

Walcott's argument critically highlights how the very approach to building an inclusive space can be misleading and unethical, undermining the multiple and varied differences. The approach to "diversity" then shows that the white gaze can set both the vector and the boundary of decolonial future making, including who belongs to this space and how.

Education, the very place with a mission of producing a democratic citizen, has too operated on, and therefore perpetrated, the structure that is anti-Black, as Walcott pointed out, through monolingual and monocultural ideologies. In the United States, where we are currently situated, such a monolingual ideal has been easily observed and circulated across different spaces of language and literacy instruction. In Producing Good Citizens, a literacy and writing studies scholar, Amy Wan (2014) traces the genealogy of how literacy instruction has shaped, and been shaped by, citizen-making efforts in the United States. Focusing on the role of literacy instruction for work preparation of students in the early 2oth century, Wan (2014: 5) shows how literacy served as a means to "certify and then direct students into particular roles in the emerging mass-manufacturing economic system". The connection between literacy instruction and citizenship, or conversely, the relationship between illiteracy and discitizenship that Wan acutely teases apart concerns how the conceptualization of language and literacy also shapes the discourse of who is considered a "right" and "legitimate" democratic citizen and delineates language and literacy practices that are deemed "appropriate" for them to participate as a civic citizen. The notion of sociolinguistic appropriacy like "citizenship" is a heavily loaded value that weighs against the marginalized communities, including involuntary immigrants, and is continuously used against those who already participate in civic engagement, yet are not recognized as "legitimate" citizens.

The deeply entrenched English-only, monolingual ideology, namely, that a particular variety of English is the one and only language that matters for 
students' learning as well as socioeconomic mobility and success, indeed positions racialized, language-minoritized communities as "deficient" and "languageless" (Rosa 2019). As refuted by many scholars (e.g., Avineri et al. 2019; Heller and McElhinney 2017; Flores and Rosa 2015), and particularly, linguistic anthropologist, Jonathan Rosa (2019), through his notion of the ideology of "langualessness," such a view frames language-minoritized students of color not only as deficient but also as a perpetual Other. And yet, the monolingual ideology is loud and alive, even among those who identify themselves as "liberal" in the political spectrum. For instance, the idea of 30-million-word gaps, which views language-minoritized children as lacking 30 million words (compared to children in the white upper-middle class), has been used by the Obama administration as a way to push universal pre-K education (Flores 2018). This debate is only one of many examples that attest how scholarly knowledge-making and education contributes to, or remains limited in furthering, democratic ideals with the shared goal towards justice and, ultimately, alternative realities for many disenfranchised groups.

These discussions point to how the colonial logic is deeply embedded in our discussion of different bodies, their belonging, and doing of language and literacies - the everlasting impacts of the European and US settler colonialism that Aníbal Quijano (2007) calls "coloniality." In other words, the way languageminoritized students are identified as "deficient," "languageless," and "Other" has less to do with their actual abilities, but more with what institutions fail to see as valuable languaging practices. As long as institutions continue to operate on the colonial logic that centers the white gaze, language-minoritized and racialized students and their communities as well as their embodied experiences and knowledge will continue to be viewed as "deficient" and "irrelevant" through the workings of the deficit view.

\section{Languaging toward a Decolonial Option}

Although the attention to coloniality (Quijano 2007) has a long history in research on issues related to inequalities and inequities, efforts to actively work against the everlasting consequences of colonialism have recently come to draw more attention from scholars in language and literacy research-to the extent that Maldondo-Torres (2007) notes such collective attention as "the de-colonial turn." While being open to pluriversality rather than universality is key in pursuing a decolonial option and decolonial thinking, Walter D. Mignolo (2000, 2009, 2011, 2018) has particularly emphasized "epistemic delinking" (2009: 15). Building on Quijano's (2007) imperative on liberation from the 
coloniality, Mignolo (2011) finds that such liberation starts from delinking from the colonial, and therefore, Western and modernist thinking and being, including the categories that emerged from such thinking and modes of construction that enabled these categories. In other words, decoloniality lies in "de-linking from the spell of the rhetoric of modernity, from its imperial imaginary articulated in the rhetoric of democracy" (Mignolo, 2011: 48, emphasis in original). In this sense, epistemic delinking is also a form of "epistemic disobedience" (Mignolo 2009: 15) that asks us to find an alternative perspective through which we can understand what is noted as fundamental terms such as language and literacy, and, by extension, our past and future. This epistemic delinking, in its extension, is an active refusal to recognize and value people and their multiple ways of being, knowing, and living, away from the white gaze (Grande 2018; Tuck and Yang 2017), as a dominant lens through which people and their various doing and being are (de)valued. Therefore, attending to how the white gaze operates and how we can delink our ways of being, knowing, and doing remains as an essential task in working toward just, equitable, and humanizing futures as part of ensuring the pluriversality that epistemic disobedience looks to build.

In research on language and literacy, the epistemic delinking has been emphasized around critiquing how language and literacy has been conceptualized by and with colonial terms. Focusing on African contexts, Sinfree Makoni $(1998,2003)$ has importantly argued that the invention of our named languages is a colonial product; he suggested that disinvention of this construct is a way of delinking and moving beyond the mode of thought that worked, and continues to work, to oppress our own understanding of language and literacy. Makoni's idea of disinvention, originally conceived to address African languages and multilingualism in Africa (Makoni 1998, 2003; Makoni and Pennycook 2007), has recently been extended to a disinvention of English (Ishikwa 2019; J. Lee 2017).

The idea of disinvention offers an example of how decolonial thinking can be "operationalized," which still demands more work. After all, the goal of a decolonial framework is to disrupt the social order of the existing world (Tuck and Yang 2018), and doing so-like any agenda of a social transformation-requires our action, grounded in material realities. Articulating the possibilities of a decolonial turn in the context of the English language education, Kumaravadivelu (2016: 82) has also pointed out the importance of "a collective, concerted, and coordinated set of result-oriented actions". Rethinking ways to dismantle white supremacy and anti-Black racism then requires our concrete actions, or praxis of knowledge making, to keep our work accountable for social challenges. We engage with this question of "how" of this "collective, 
concerned, and coordinated" action in the next section, first focusing on "where" of our theory building can be based on.

\section{Sociolinguistic Activism via Centralizing Languaging for Social Change in the "Streets"}

As briefly discussed earlier, epistemic delinking requires a shift in our thinking of what counts as legitimate knowledge and where we look to build knowledge. This questioning of "what" and "where" demands interrogating "who" holds legitimate knowledge "where," not only in terms of the locus of enunciation for the researchers themselves, but also what particular social space and/ or whose knowledges and struggles we as researchers examine to theorize languaging for social change. What is recognized as legitimate knowledge shapes what we understand by "theory" and who produces. Therefore, interrogating whose knowledge is worthy of theorization becomes part of a series of questions that epistemic delinking should embrace. In this sense, this interrogation can crucially guide working to shift what Lewis Gordon (2021:15) calls the "geography of reason" - the patterned way "legitimate" knowledges and theories are constructed, embodied, and situated across different locales. And we believe attending to the "streets" is one way of pursuing this interrogation for epistemic delinking. The call for this inquiry may not be groundbreaking, considering calls made by New Literacies Studies as well as others to examine different ways of doing language and literacies beyond the school. For instance, Rymes and Leone (2014: 28) have specifically argued for citizen sociolinguistics as "a more nuanced and emic qualitative approach that taps into circulating discourses about language." This emic approach, they argue, should also account for the new media's participatory culture as well as increased mobility and connectivity between people and traditionally recognized categories of language, ethnicity, and nation-state.

Yet, despite the numerous calls to look beyond classrooms as a site of languaging, our theorization of how people make meaning is still largely dependent on language use and interactions that occur in educational contexts (Ortega 2015). More specifically, classrooms and institutional spaces are often perceived as a place to look to the "ideal" languaging — so much so that it often creates a chronotope of seeing a certain language as the "future" (e.g., standardized English, "academic" English) and minoritized languages as "past" (Flores, Lewis, and Phuong 2018). Research that focuses on classrooms and other educational contexts in and of themselves is not what we are problematizing; instead, at the core of our argument is in the very need to understand 
any space - including the classroom or other educational settings—as a space fraught with the struggles of the push-pull between the structure that constantly sees students, their languaging, and learning through the white gaze and the often invisible labor that our students and their communities engage in to contend this white gaze (Baker-Bell 2020; Gilyard 2016; Kynard 2013; Tuck and Yang 2018). We see recognizing this push-pull, and therefore, the political nature of any languaging, including the corollary minoritization and hierarchization among people and their languaging, as an important first step to attend to the "streets." In order to dismantle the colonial logic and build decolonial futures, we cannot conceive our work as apolitical, or a neutral vehicle through which to disseminate universal knowledge outside the space where people work to fight against various kinds of injustices.

"Streets," in any physical configuration, function as a space for a variety of activities. And also, they often become a symbol for social movements and activism for various struggles where people gather to demand social change and, therefore, bear their own history and collective memory, shaped from the historicities of people who occupy the space-both on individual and collective levels. This memory and meaning of the space is constructed by languaging that the people engage in - that is, embodied, negotiated, dynamic, and performative practices. (García and Li 2014) In a similar way, it is our languaging, as mediating activities of social movement and activism, that shapes the unpredictable future. From this perspective, the "streets" are an important space that construct and manifest a sociolinguistics of social change, struggles, and protests — however much "(in)visible" this work may be — that leads up to social transformation, and that provides us with insights on the connection between languaging and social change. In this sense, a sociolinguistics we are advocating is work that is grounded in struggles of racialized and otherwise disenfranchised and minoritized people and their "proposal-in-progress' speaking to emergent political possibilities, plural histories, and hopeful future" (Comaroff and Comaroff 2020).

Attending to the "streets" does not necessarily mean that we are physically "there": (though one should when possible) rather, it means engaging in a series of embodied, situated, and affective actions that aim for social transformation, as intersected with socioculturally and materially manifested power structure "in, through ... and beyond language" in a local context (Avineri et al. 2019: 145). With this understanding of attending to the "streets," we envision that the classroom too should be recognized as a kind of "streets" where political actions and movement are unfolding. This view makes blurred and untenable the problematic distinction between the classroom as an academic space and the world "out there"-the excuse often 
drawn by those who halt the work for equity and justice. In fact, trying to draw a boundary between the "streets" and the academic space, or not recognizing power struggles in any space, is misleading, if not futile and illusionary. In this sense, social movements and struggles should be centered in our work as an educator and a researcher in building new frameworks, and thereby, decolonial futures in which the disciplines actively disrupt the anti-Black, racist, and otherwise discriminatory political climate.

What this imperative points to is that the field has a great deal to learn from those who are making such changes through and with languaging. And it is important to note that our minoritized students have been leading many social and political fights. The history of student activism in higher education in the U.S. and beyond, for instance, shows that students have always been at the forefront to make their learning spaces, if not the society, more equitable and democratic. ${ }^{3}$ Some recent examples show that it is our undocumented students who organize to prevent deportations of other undocumented students and communities (Muñoz 2015; United We Dream, 2018) and their literacy to write their citizenship and belonging into existence while speaking against unjust and unequal realities (Alvarez forthcoming). Concerned Students 1950 Mizzou at the University of Missouri, a group of student protestors who organized a response to Michael Brown's murder by the police, have raised the issue of how "inclusion" and "diversity" in U.S. universities are often used to brand the university but the institutions never truly represent such values in their action and structure (Ervin 2019). During the 2014 Hong Kong protest against their electoral system reform, among the protestors was the Hong Kong Federation of Students, which has a long history as an activist group that participated in the Umbrella movement. And since 2019, college students, along with many other protesters, again took to the streets for their democracy movements against Chinese Communist Party's growing suppression. Similarly, it was South Korean female college students at Ihwa university who occupied the campus and used a K-pop song as a way to gain public attention in their protest against the school's neoliberal model of "selling degrees." Their continuous protests and increased public vigilance on the issue led to further investigation of South Korean then-president, Park Keun-Hye, and ultimately to her impeachment. In South Africa, students led the \#FeesMustFall movement to success in 2015-2016, despite the police brutality and violence waged

3 We do not intend to flatten our students and their civic engagement and political participation in any sense by making this claim. Rather, our point is to acknowledge that the work that they participate in is often rendered silent, illegitimate, or irrelevant due to the colonial formulation of what counts as legitimate ways of languaging. 
on their peaceful protest. Since the global pandemic hit the world in 2020, it is our youth who have taken their activism to both online and offline spaces to continue their work, despite their own struggles and challenges (Rosenblatt 2020). The examples are countless.

Despite rich and critical literacies that underwrite students' activism work, their active involvement in their right to education, and by extension, future making has not been always understood or examined as languaging work in much of sociolinguistics research. Indeed, it has been argued that the attention to language-minoritized student protests and activism needs to be recognized as a crucial form of political language and literacy practices-more notably and explicitly by scholars in Composition and Rhetoric, Literacy Studies, and Education (Alim and Paris 2017; Alvarez forthcoming; Kynard 2013). For instance, compositionist and literacy scholar Carmen Kynard (2013) traces Black Freedom Movement throughout much of the 2oth century in the U.S. in her discussion of how their struggles and protests shaped composition and rhetoric as a discipline. As one crucial site of Black Freedom movement, Kynard examines the work of Historically Black Colleges and Universities (HBCU s) and Black teachers and students against Jim Crow. In particular, Kynard points out the erasure of Black and Puerto Rican students in their contribution to desegregation of educational institutions in New York City, as part of the larger civil rights activism scene in this context. Kynard focuses on demands of both of these groups for equitable education, including more faculty of color, rights to ethnic studies classes, and more fair admission and support for these students at City University of New York. As Kynard emphasizes, the discussions and policies that were instated based on these students' protest had a long-lasting impact on the "support" programs that were created. Equally importantly, these students and their languaging, including literacies, were the very forces that shaped the activism, which greatly contrasts with the deficit view that was inscribed on these students' bodies and language, often rendering them as "underprepared," "at risk," "illiterate" to name a few. This way, Kynard compels us, researchers and educators, to think about how what these students have shown us should be understood as a form of critical "out-of-school" literacies.

Another example that pays much needed attention to students' languaging work in the "streets" can be found in the work by Sara P. Alvarez (forthcoming). Based on her 3-year long ethnographic work, Alvarez examines multilingual practices of a self-outed undocumented immigrant rights activist and college student, Jung. Alvarez analyzes Jung's engagements with different writing situations for different purposes: a haiku for an immigrant community organizing fellowship application materials, a spoken-word poem for an open mic event where his non-profit organization participated in to celebrate 
Immigrant Heritage Month, press releases, email writings, and other multilingual languaging practices that he engages in as part of his everyday life as an activist. As she illuminates, Jung's language and academic and professional writing practices are grounded in his lived experiences. The significance of his multilingual practices, as Alvarez emphasizes, is in that Jung writes against and beyond the "walls" of various kinds that have been imposed on him through his languaging practices. More precisely, these "walls" included both the legal and societal imposition of who Jung can be as manifested through discourses of Asian model minority myth, education and employment opportunities and rights, family separation, and recognition of human rights, just to name a few. As Jung contends with these "walls" through his various languaging practices, Alvarez crucially points out how these "walls" are intersected with monolithically conceived notions of language, nation, belonging, and academic writing that have been shaped through the white gaze and therefore continues to racialize multilingual writers like Jung.

What these two scholars clearly point to is that the students' languaging practices in their activism not only challenge what is "traditionally" defined as prestigious forms of language and literacies, but also push forward the parameters of the democratic ideals that never protected these students. More specifically, the kinds of languaging that are examined in Kynard's and Alvarez's work demonstrate how the students' semiotic repertoire-both linguistic and rhetorical -is not only sociocultural and historical, but also an embodiment of their experiences of racialization, capitalism, global migration, and the boundary-making of nation-states and their making of citizen and (il)legality. And yet, discussions about language and diversity have not always centered the embodied, sociopolitical, racial, and legally bound nature of semiotic repertoire in relation to its speakers and their positionalities. As an important site of change-in-the-making and critical literacies, languaging that underwrites activism, social movement and political engagement compels us to see how languaging works alongside the coloniality of onto-epistemologies towards social transformation and justice. This way, sociolinguistics of the "streets" can and should contribute to rewriting frameworks of and approaches to language and literacies that our current knowledge production has failed to value and recognize.

To contribute to dismantling white language supremacy, disrupting the reproduction of racism, and ultimately realizing decolonial possibilities, we must highlight the role of languaging in social change and the ways in which our theories of languaging can be utilized to challenge the discriminatory environment in which we are currently living. This points to the necessity of our theory and research to be built on more specifically embodied and situated 
positions and places, including how languaging is drawn and contributes to decolonial future making. In this regard, we see the "streets" as an important space with a rich history of how social change takes places and therefore a site that offers us ways to better understand languaging in the move toward social change. In this co-constructed and mediated space, people bring and, therefore, navigate and negotiate many different value systems as well as ways of knowing and meaning making while fighting for justice and equity. With the understanding of differently positioned and embodied experiences of coloniality, we constitute the "streets" as a space for political engagements and activism work that has much to offer in our research on languaging and social transformation, equity, and justice and ultimately, sociolinguistic activism work. Further, we argue that the work on the sociolinguistics of the "streets" should account for a political nature of meaning making, including but not limited to the racioethnic hierarchization as (re)produced and perpetrated by the colonial language ideology to work toward decoloniality.

In the following, we suggest three important considerations, implications, and challenges in attending to the "streets", while also being conscientious of different positionalities and embodiments through which languaging takes place. We approach this discussion as a matter of how knowledge making should be guided and valued beyond traditional constructs in research methodology such as "objectivity" or "trustworthiness."

\section{"How" of Attending to Languaging in the "Streets": Attuning to Struggles of the Minoritized Communities as a Site of Embodied Knowledge}

Activities on the "streets" are mediated by various kinds and levels of sociomaterial and ideological resources and constraints. Therefore, attending to languaging in the "streets" requires a more nuanced understanding of how language is situated around, emerges, shifts, and evolves dynamically by, with, and between different people with different historicities and positionalities with(in) and beyond these materialities. In one sense, attending to the "doing" of language in the "streets" also requires our analytical tools to capture dynamic, embodied, and locally situated meaning making that is unfolding unpredictably. In this manner, such attending also makes language one of many meaning-making modalities, as situated in a given ecology, differently embodied by people.

From his analysis on the "casual and unplanned encounter" with a child, Ndhlovu (2018: 3) highlights that new theorization of language away from the 
colonial knowledge making practices needs a method different from the conventional research methods. More precisely, attending to languaging in the "streets" reinforces the importance of a nimble framework and method that takes emergence, embodiment, and dynamicity of meaning making practices as given. Accordingly, this attention to dynamic meaning making also has potential to make imperative methodological innovation of tools adaptable to radically changing contexts, inclusive of all semiotic resources, beyond linguistic ones, as essential meaning-making elements. Given the unpredictability of any communicative encounter, this approach should also account for language heterogeneity as a communicative norm. In this regard, recent theoretical advancements in applied linguistics that center mobility and translinguality can be helpful. Beyond the focus on named languages, scholars have argued for the importance of "semiotic assemblage" (Pennycook 2017) and the way people draw on "spatial repertoire" (Canagarajah 2017; Pennycook and Otsuji 2015), including non-linguistic (e.g., gaze, gesture, posture) and non-human elements (e.g., artifacts, materiality of the place, layout of the space, relations among them). As Pennycook (2017: 278) emphasizes, the spatial repertoire "gives us a way to address the complexity of things that come together in the vibrant, changeable exchanges of everyday urban life."

This more layered, nuanced, and situated approach is useful to examine the "streets" in our transnational online spaces. In a transnational world with accelerated migration and technological advancement, "streets" that people formed online have fueled and supported many social movements, such as Arab Spring, Drop the I-word, \#BlackLivesMatter, \#HereToStay, \#MeToo, and \#StopAAPIHate (Bonilla and Rosa 2015; Smalls 2019). As the digital environment and technologies have provided different affordances as compared to physical spaces, examining how people transform digital spaces into "streets" provides us another window through which we can understand how people do language to effect social change. How we interact with and occupy physical places is shaped by emergent and invisible ecological forces, and examining online spaces and the way people do language to make a social change can offer us a more nuanced understanding of how people recognize, build, and use their linguistic and other semiotic resources, including their "spatial repertoire." For instance, hashtags are well known to be used to build visibility of issues and (re)construct social movements and the collective memory towards the physical locations where hashtags were originally emergent from, as shown in the case of \#BlackLivesMatter and Missouri (Bonilla and Rosa 2015; Smalls 2019). Live streaming has also been frequently utilized by the activists of the "movements of the squares" in Egypt, Spain, Greece, and US as a way to archive protest events or other related decision-making 
processes as they are being unfolding, without filtering an intense, "raw" affect (Kavada and Treré 2019). As mentioned briefly earlier, the coviD-19 pandemic has heightened the significance of the online spaces for not only accessing information but also building social movements. Many activist groups organized virtual gatherings and webinars for coalition building and sharing stories, strategies, and resources for self- and community care and training, launching new initiatives, and crowdsourcing multilingual documents, among others (Valls 2020). Attending to the "streets" in this sense can help to understand how activists and other social movement participants navigate digital and physical spaces, engaging with various apps, technologies, and other materialities while negotiating ideological and affective aspects of this work (Dache and Mislán 2019).

In thinking about how we attend to the "streets" and the many happenings in this space, we do not necessarily relay a belief that particular "tools" are more important for decolonial research. Consideration for the methods and methodology is certainly important, and as a researcher, we need to remain keen and conscientious about how we use the tools in ways that achieve our goals toward decolonial future-making as well as its processes. However, we are not arguing that particular methods are superior or better suited in research on languaging in the "streets." What's crucial in attending to the different "streets" as transnationally situated, cultivated, and enacted is what Gordon (2021: 42) calls a "teleological suspension of disciplinarity," - the act of "pushing methodological fetishism and disciplinary nationalism to the side for the sake of reality." In this manner, researchers' own critical, creative, and conscientious engagement with and (dis)invention of tools of examining and representing data and knowledge becomes imperative in going beyond the traditionally recognized and categorized methodologies and methods.

The emphasis on the emergence in languaging in the "streets," present the need to attend to meaning making as locally emergent yet across different temporalities and spatialities. And such inquiry contributes to "how" social change and transformation occurs along with materialities and semioticities, as interwoven with dominant ideologies. At the same time, it is important to point out that the emergence and becoming of the "streets" are constituted by different bodies of individuals as they actively construct the very space that leads to the transformation. We turn to the importance of attending to the different bodies and positionalities in the work of attending to the "streets" in the next section. 


\section{Whose Bodies and Languaging?: Centering Bodies \& Positionalities in the "Streets"}

As Mignolo (2018) argues, establishing a form of pluriversality begins with "epistemic delinking," leaving the possibilities of subsequent and future re-linking, followed up with materialization of a decolonial thinking. Yet, in building our theory of language and literacy, we need to consider how our theorization of language and literacy is grounded in concrete lived experiences and the contexts in which these lived experiences are situated, or what Mignolo (2000) terms the locus of enunciation. Although coloniality may be universal, the individual experience of coloniality is never the same in terms of weight, opacity, and texture. What these varied and hierarchized impacts of coloniality suggest in enacting decolonial possibilities in knowledge making is then centering the locus of enunciation to attend to not only what different bodies speak from their locale as part of their knowledge making, but also how these different bodies work to construct and cultivate this space of knowledge making and languaging.

Research examining the activities and languaging in the "streets" is implicated in this very aspect of decolonial future making. Any space is constructed by people and the values that they bring; in other words, this inquiry ultimately means that the question of who is doing this languaging work, how, and how this labor is perceived needs to receive more attention in examining language practices and assemblages that are the result of dynamic ecological co-laboring. The positionalities of the speaker and their embodied experiences become the key and how the labor that aims to affect the similar goal looks and sounds and gets its job done.

For instance, noting the unequal realities for different language speakers-often language-minoritized and racialized, Lippi-Green (2012) poses that individuals determine who has more responsibility to negotiate the communicative burden and that such decision making is filtered through their ideological standpoint in language. Indeed, Black literacy scholars and educators, Gilyard (2016), Kynard (2013), Smalls (2019), and Baker-Bell (2020) have argued for the need to pay attention to the unequal realities of language-minoritized students' languaging. Turning his attention to the rhetoric of our theoretical framework, Gilyard (2016) acutely critiqued translingualism, despite its liberating ideas, for its lack of attention to differences within and across language practices as rooted in individuals' experiences and identities, including, but not limited to, racialization. Kathryn Smalls (2019) emphasizes the varied Black Englishes and Languages that constitute Black Twitter, and reminds the irreducibility of Blackness to a homogenous and monolithic quality and 
experience in this space. In reflecting on her female students of African Diaspora and their varied experiences and stories of colonialism in her teaching, Kynard (2013: 17) poses, "It is . . this kind of stance that can best capture an ideology in which Black Language is not merely a set of structures and usages to study and quantify, but a polemic from which to challenge the social reproduction of schooling, society, and literacy paradigms." In this manner, Kynard emphasizes that Black language is also built upon and reconstituted by Black social movement for racial justice and equities, encompassing their struggles as grounded in their lived experiences of unequal realities. Echoing Kynard's point, Baker-Bell (2020: 16) has pointed to the importance of attending to different communities' experiences of linguistic racism intersectionally and emphasized the need to carefully approach "how communities of color experience linguistic discrimination differently than white linguistically marginalized communities." What their valuable critique points to is that our theorization of languaging, as dynamic meaning making, must reflect different histories within which individuals are positioned and experience different kinds and magnitudes of violence and its consequences. In other words, we must account for how different speakers of varied positionalities are differentially affected by coloniality to make our work relevant to social challenges.

The importance of attending to bodies is particularly significant, as society (including our knowledge making), despite its multilinguality, is structured through dominant monolingual, monocultural, and ableist assumptions in ways of being and meaning making. For instance, the discourse of multilingualism in the US is often understood as an important competence and contribution to harmonious nation building, yet the research often overlooks the raciolinguistic stratification and nativist view deeply entrenched in society (Flores and Rosa 2015). To the issue of bodies and embodiment, Paris (2019) makes an important point in the need to attend to positionalities of people and their lived experiences. Drawing on the Wall Street Occupy movement, Paris (2019) asks how we occupy language and how the way we occupy language leads to social change. Yet, even the way we occupy language, or languaging more broadly, is hierarchized. Focusing on Deaf communities' languaging, De Meulder, Kusters, Moriarty, and Murray (2019) also make a point on how our research frameworks and concepts are not fully attending to the politics of languaging. Taking the case of translanguaging, the authors contend that despite the contribution, translanguaging as a framework does not fully recognize politics of embodiment such as one among Deaf people. The authors argue, "recalling the sensory asymmetries inherent in blended spoken and signed interactions, we must also be mindful of sensory privileges which structure such interactions" (De Meulder, Kusters, Moriarty, and Murray, 2019: 90o). 
What is both essential and difficult here is then how we attend to the matter of who occupies language. When we start thinking about "who" occupies the language and "how," instead of just focusing on the manner in which one occupies the language against the white gaze, we start foregrounding their embodied experiences as well as the historicities in which such experiences are embedded. The focus on lived experiences in and of the "streets" ultimately urge the researchers to account for differently embodied experiences.

We need to be cognizant of the ways that our research recognizes the specificities of experiences by different people and how we create, disrupt, and sustain (new) relations throughout the research. The significance of attending to embodied experiences and different knowledges embedded in such lived experiences while examining the "streets" then also importantly questions how researchers' own positionalities create, disrupt, and sustain relations that are rooted in the colonial knowledge making practices. We discuss how attending to the "streets" also demands different relationalities between researchers and research participants and conceptualization of researchers and research in the rest of the article.

\section{From Objective Knowledge Making to Answerable Relations}

One more important way that researchers are implicated in examining the "streets" is how we position ourselves in this space. And this question of "how" of our positioning alongside our research participants is a question of how we occupy the "streets" with our participants. We argue that this question, too, requires epistemic delinking from the colonial research measure in terms of the relations we form with them as we challenge the existent white supremacy and colonial relations that are prevalent both in academia and beyond. Bucholtz (2018: 352) states, "In order to foster social justice, sociocultural linguistics must shift from a liberal perspective of benevolent scientific objectivity to a more politically engaged stance". Bucholtz's argument points to the need of new terms to understand research validity and rigor, different from what's "scientifically rigorous" and "objective" in the modernity-often thought in the void of bodies, relations, and affect. This shift urges us to engage with the issue of our own positionalities as researchers and the relations we assume, impose, and forge as we conduct our research. In this manner, the relations between our positionalities and our research participants matter as much as what our research on the "streets" aims to examine.

The relations between the researcher and the researched, and other relations that may emerge throughout the research, points to an important question in 
terms of through what terms our research validity, legitimacy, and ethics are understood and evaluated. In the positivist paradigm, a value is placed on a distance between researchers and research participants in the name of achieving a "neutral" stance, and thereby "objectivity." Despite the recent focus on reflexivity, such work often discusses reflexivity only as a way to report "transparency" or "trustworthiness," the ultimate purpose of which is to "prove" the truth value of the claim. Although such values make the researchers more accountable for the relationship with the researched, they do not necessarily suppress the gaze that they may impose on the researched.

Crucial to our focus on the role of languaging as involved in unequal social realities and accounting for social change is how we use and reflect on our positionalities in our research toward justice. In a way, adopting an activist stance in spaces fraught with social inequities and inequalities challenges our work with differently racialized individuals who are often dispossessed, displaced, and disenfranchised. Tuck and Yang (2018:4) note, "Social justice is a way to mark a distinction from the origins and habits of almost all disciplines which emerged in the 19th and 2oth centuries and are rooted in colonialism and white supremacy." In this sense, a move toward social justice is "a choice away from pathology and linearity" (Tuck and Yang 2018:5, emphasis original)—the very qualities that characterizes the positivist and developmental frameworks that have been governing much of the "traditional" and ongoing research on languaging. The active choice away from these values is also a political one that should guide our sociolinguistic protests for social transformation-a refusal to maintain a framework that categorizes and excludes certain languages, and by extension, its speakers, through the working of raciolinguistic stratification (Flores and Rosa 2015; Grande 2018). In other words, we need a different way to think about our research, our role as a researcher, and our relation to knowledge and participants.

In this regard, Patel's (2016) call for approaching our research in terms of answerability provides us an ethical and humanizing way of thinking of research in the "streets." Patel problematizes how the colonial logic of "ownership" is deeply entrenched in educational research, as shown in our understanding of knowledge from our research projects as something we "own" and the frequent pathologizing approach to and portrayal of communities of color as those who "need" and "lack." Patel (2016: 72) urges researchers to move away from the discourses and practices rooted in the idea of "ownership"-away from "pursuing knowledge as something to be owned, in the interests of it being rewarded with status and capital". Instead, Patel emphasizes "answerability" as a means to decolonize our knowledge-making practices and move towards knowledge-sharing practices. Ultimately, remaining answerable, Patel 
explains, "includes aspects of being responsible, accountable, and being part of an exchange" (Patel 2016: 73).

Accordingly, reconceptualizing the core relation in our research also means that we need to address the difficult and challenging question of what "good" our research brings into the world for disenfranchised people beyond generating the knowledge or fulfilling the purpose of what Kumaravadivelu (2016) has called "intellectual extension." Universities, often viewed as the knowledge-making "machine," with discourses such as "publish or perish" or "fake it till make it," are responsible for not only the shape and texture of the knowledge economy but also the very function of how this knowledge economy serves humanity. As Connell (2019: 179) argues in Good University, "The task of decolonizing universities is ... linked to our capacity to re-think the global economy and human mutuality". What this ultimately points us to is that as much as knowledge itself is an important outcome of the research, we should also think about the consequences of the pursuit of that knowledge: How does our research remain answerable to those our research is grounded in and learns from? What does our research generate? And whose interest and humanity does our research serve?

In bringing or centralizing the "streets" into our classroom and/or research, this also means that we need to reconceptualize what our identities mean within a university but also as a citizen. The political engagement ultimately points to how we understand our role in dismantling racist systems of knowledge making as well as advancement of knowledge itself. This includes necessary interrogation and reflection on how we navigate and negotiate our positioning as situated in a web of multiple structures and systems of knowledge and institutions. Despite the rich knowledge and languaging our youth show through their activism, a lot of youth participatory action research that centers youth's knowledge points to how teachers and administrators view the knowledge generated from youth as invalid or not cogent to their everyday teaching/learning or the transformation that schools need to better serve students (Welton and Bertrand 2019). In this sense, social justice is also a cognitive justice that demands an epistemological shift among researchers as to who can be in charge of producing knowledge and how we stand alongside this knowledge and its people (Caraballo, Lozenski, Lyiscott, and Morrell 2017; Santos 2016).

\section{Conclusion}

Research on languaging has long critiqued the unequal realities and the role that our understanding of language and literacy plays in these unequal realities. To move beyond the critique and work toward building decolonial futures, 
we need to center the very process and practice of laboring of and for social change in our research. Centering the "streets" along with people in the "streets" in our work can help us to capture the language that people do in the moment of uncertainty, unpredictability, and fluidity, and further the work of decolonial future making where the connection between language and diversity is no longer conceived and enacted through the white gaze. To do so, we need a framework that allows us to analyze moment-to-moment dynamic meaning making that does not assume one language as a communicative norm.

Yet, such work has to be done without losing sight of power and its working on and transformation by the people. Researchers need to keep in mind the ways research methods are discussed and (de)valued can delineate what's valid and legitimate in our knowledge making. More specifically, research methods adopted in examining the "streets" should be able to attend to the politics of meaning making not only in a situated manner, but also demand reflexivities on the researchers themselves, conscientious of unequal realities in which individuals are differently situated in, including the raciolingusitic stratification that shapes their languaging and lived experiences. And we researchers could very well participate in and perpetuate this very raciolinguistic stratification without changing how we orient to our research. In this regard, focusing on the role positionalities play in different languaging also requires a more conscientious take on how researchers can account for their own positionalities in knowledge making. This also means paying attention to how and whom we are paying attention to in addition to the stance we are adopting. As discussed previously, any work that aims to contribute to building a just and equitable world requires actively resisting pathology by not portraying our informants from a perspective of pathology. Reimagination and building decolonial futures calls on scholars and educators alike to examine how we as scholars are participating in this process through what practices as well as how what we do perpetuates the positivist paradigm of research rather than building a pluralistic ecology of knowledges (Santos 2014). It is to this very self-reflexivity of different levels and kinds of change that we aim to invite our colleagues to work toward as we think of the seemingly "unthinkable" and do the seemingly "impossible."

\section{Bibliography}

Alim, H. Samy and Django Paris. (2017). "What is Culturally Sustaining Pedagogy and Why Does it Matter?" In Culturally Sustaining Pedagogies:Teaching and Learning for Justice in Changing World, edited by Django Paris and H. Samy Alim, 1-23. New York, NY: Teachers College Press. 
Alvarez, Sara P. (forthcoming). "Writing on the Wall: Literacy Education and the Resurgence of Nationalism" In Writing Education and Resistance to Isolationism, edited by Xiaoye You, David Martin, and Brooke Schreiber. Logan, UT: Utah State University Press.

Avineri, Netta, Laura R. Graham, Eric J. Johnson, Robin Conley Riner, and Jonathan Rosa, eds. (2019). Language and Social Justice in Practice. New York: Routledge.

Bagga-Gupta, Sangeeta. (2004). "Challenging Understandings in Pluralistic Society." Utbildning \& Demokrati 13(3): 11-36.

Baker-Bell, April. Linguistic Justice: Black Language, Literacy, Identity, and Pedagogy. New York: Routledge. (2020).

Bonilla, Yarima and Jonathan Rosa. (2015). “\#Ferguson: Digital Protest, Hashtag Ethnography, and the Racial Politics of Social Media in the United States." American Ethnologist 42(1): 4-17.

Bucholtz, Mary. (2018). "White Affects and Sociolinguistic Activism." Language in Society 48: 350-354.

Canagarajah, Suresh. (2013). Translingual Practice: Global Englishes and Cosmopolitan Relations. New York: Routledge.

Canagarajah, Suresh. (2017). "Translingual Practice as Spatial Repertoires: Expanding the Paradigm Beyond Structuralist Orientations." Applied Linguistics 39(1): 31-54.

Caraballo, Limarys, Brian D. Lozenski, Jamila Lyiscott, and Ernest Morrell. (2017). "YPAR and Critical Epistemologies: Rethinking Education Research." Review of Research in Education 41: 311-336.

Comaroff, Jean and John Comaroff. (2020). In Knowledges Born in the Struggle, edited by Boaventura de Sousa Santos and Maria Paula Meneses. New York: Routledge.

Connell, Raewyn. (2019). The Good University: What Universities Actually Do and Why It's Time for Radical Change. London: Zed Book.

Dache, Amalia and Cristina Mislán. (2019). "Defining the Struggle: Epistemological Explorations of Social Geography and Digital Space in Ferguson." In Rise Up! Activism as Education, edited by Amalia Dache, Stephen John Quaye, Chris Linder, and Keon M. McGuire, 97-114. East Lansing: Michigan State University Press.

De Meulder, Marrtje, Annelies Kusters, Erin Moriarty, and Joseph J. Murray. (2019). "Describe, don't prescribe. The practice and politics of translanguaging in the context of deaf signers." Journal of Multilingual and Multicultural Development 40(10): 892-9o6.

Ervin, Storm. (2019). "Vignette: A Resistance Journey in Higher Education." In Rise Up! Activism as Education, edited by Amalia Dache, Stephen John Quaye, Chris Linder, and Keon M. McGuire, 33-48. East Lansing: Michigan State University Press.

Flores, Nelson, "Making Millions off of the 3o-Million-Word Gap." The Educational Linguist, May 31, 2018, URL: https://educationallinguist.wordpress.com/2018/o5/31/ making-millions-off-of-the-3o-million-word-gap/. 
Flores, Nelson and Jonathan Rosa. (2015). "Undoing Appropriateness: Raciolinguistic Ideologies and Language Diversity in Education." Harvard Educational Review 85(2): 149-171.

Flores, Nelson, Mark C. Lewis, and Jennifer Phuong. (2018). "Raciolinguisitc Chronotopes and the Education of Lantinx Students: Resistance and Anxiety in a Bilingual School." Language \& Communication 62: 15-25.

García, Ofelia and Li Wei. (2014). Translanguaing: Languaging, Bilingualism, and Education. New York: Routledge.

Gilyard, Keith. (2016). "The Rhetoric of Translingualism." College English 78(3): 284-289. Gordon, Lewis. (2021). Freedom, Justice, and Decolonization. New York: Routledge.

Grande, Sandy. (2018). "Refusing the University." In Toward What Justice?: Describing Diverse Dreams of Justice in Education, edited by Eve Tuck and K. Wayne Yang, 47-65. New York: Routledge.

Heller, Monica and Bonnie McElhinny. (2017). Language, Capitalism, Colonialism: Toward a Critical History. Toronto: University of Toronto Press.

Ishikwa, Tomozaku. (2019). "Complexity of English as a Multilingua Franca: Place of Monolingual Standard English.” In English as a Lingua Franca in Japan: Towards Multilingua Practices, edited by Mayu Konakahara and Keiko Tsuchiya, 91-1og. Palgrave: Macmillan.

Kavada, Anastasia and Emiliano Treré (2019). "Live Democracy and its Tensions: Making Sense of Livestreaming in the $15 \mathrm{M}$ and Occupy" Information, Communication \& Society 23(12): 1787-1804.

Kumaravadivelu, B. (2016). "The Decolonial Option in English Teaching: Can the Subaltern Act?" TESOL Quarterly 50(1): 66-85.

Kynard, Carmen. (2013). Vernacular Insurrections: Race, Black Protest, and the New Century in Composition-Literacies studies. Albany: Suny Press.

Lee, Jerry Won. (2017). The Politics of Translingualism. New York: Routledge.

Lippi-Green, Rosi.(2012).English with an Accent. Language, ideology, and discrimination in the United States (2nd edn). New York: Routledge.

Makoni, Sinfree. (2003). "From Misinvention to Disinvention of Language: Multilingualism and the South African Constitution." In Black Linguistics: Language, Society, and Politics in Africa and the Americas, edited by Sinfree Makoni, Geneva Smitherman, Arnetha Ball, and Arthur K. Spears, 132-152. New York: Routledge.

Makoni, Sinfree. (1998). "In the Beginning was the Missionaries' Word: The European Invention of an African Language: The Case of Shona in Zimbabwe." In Between Distinction and Extinction: The Harmonisation and Standardisation of African Languages, edited by Kwesi Kwaa Prah, 157-164. Johannesburg: University of Witwatersrand Press.

Makoni, Sinfree and Alastair Pennycook, eds. (2007). Disinventing and Reconstituting Languages. Multilingual Matters. 
Maldondo-Torres, Nelson. (2007). "Thinking through the Decolonial Turn: Postcontinental Interventions in Theory, Philosophy, and Critique-An Introduction." Transmodernity $1(2): 1-5$.

Mignolo, Walter D. (200o). Local Histories/Global Designs: Coloniality, Subaltern Knowledges, and Border Thinking. NJ: Princeton University Press.

Mignolo, Walter D. (2009). "Epistemic Disobedience, Independent Thought and De-colonial Freedom." Theory, Culture, \& Society 26(7-8): 1-23.

Mignolo, Walter D. (2011). "Epistemic Disobedience and the Decolonial Option: A Manifesto." Transmodernity 1(2): 44-66.

Mignolo, Walter D. (2018). "The Decolonial Option." In On Decoloniality: Concepts, Analytics, and Praxis, Walter D. Mignolo and Catherine E. Walsh, $105^{-244}$. Durham: Duke University Press.

Muñoz, Susana M. (2015). Identity, Social Activism, and the Pursuit of Higher Education: The Journey Stories of Undocumented and Unafraid Community Activists. New York: Peter Lang.

Ndhlovu, Finex. (2018). "Omphile and his Soccer Ball: Colonialism, Methodology, Translanguaging Research" Multilingual Margins 5(2): 2-19.

Ortega, Lourdes. (2015). "Ways Forward for a Bi/Multilingual Turn in SLA." In The Multilingual Turn: Implications for SLA, TESOL, and Bilingual Education, edited by Stephen May, 32-53. New York: Routledge.

Paris, Django. (2019). “(De)Occupying Language.” In Language and Social Justice in Practice, edited by, Netta Avineri, Laura R. Graham , Eric J. Johnson, Robin Conley Riner, and Jonathan Rosa, 184-192. New York: Routledge.

Patel, Leigh. (2016). Decolonizing Educational Research: From Ownership to Answerability. New York: Routledge.

Pennycook, Alastair. (2017). Translanguaging and semiotic assemblages. International Journal of Multilingualism, 14(3): 269-282.

Pennycook, Alastair and Emi Otsuji. (2015). Metrolingualism:Language in the City. New York: Routledge.

Quijano, Aníbal. (2007). "Coloniality and Modernity/Rationality." Cultural Studies 21(2-3): 168-178.

Rosa, Jonathan. (2019). Looking Like a Language, Sounding Like a Race: Raciolinguistic Ideologies and the Learning of Latinidad. New York: Oxford University Press.

Rosa, Jonathan and Nelson Flores. (2017). "Unsettling Race and Language: Toward a Raciolinguistic Perspective." Language in Society 46(5): 1-27.

Rosenblatt, Kalhan, "A Summer of Digital Protest: How 2020 Became the Summer of Activism Online and Offline." NBC News. Sep 26, 2020.

Rymes, Betsy and Andrea R. Leone. (2014). "Citizen Sociolinguistics: A New Media Methodology for Understanding Language and Social Life." Working Papers in Educational Linguistics 29(2): 25-43. 
Santos, Bouventura de Sousa. (2014). Epistemologies of the South: Justice Against Epistemicide. New York: Routledge.

Santos, Bouventura de Sousa. (2016). "Epistemologies of the South and the Future." From the European South 1: 17-29.

Savransky, Martin. (2017). "A Decolonial Imagination: Sociology, Anthropology and the Politics of Reality." Sociology 51 (1):11-16.

Smalls, Krystal A. (2019). Languages of Liberation: Digital Discourses of Emphatic Blackness. In Language and Social Justice in Practice, edited by Avineri, Netta, Laura R. Graham, Eric J. Johnson, Robin Conley Riner, and Jonathan Rosa, 52-59. New York: Routledge.

Tuck, Eve and Wayne Yang. (2018). "Introduction: Born Under the Rising Sign of Social Justice." In Toward What Justice?: Describing Diverse Dreams of Justice in Education, edited by Eve Tuck and K. Wayne Yang, 1-18. New York: Routledge.

United We Dream, “United We Dream," United We Dream Network, 2018, URL: https:// unitedwedream.org/.

Valls, Daniel, "Activism in Times of covid-19: A Time for Change?" Amnesty International, May 29, 2020.

Walcott, Rinaldo. (2018). "Against Social Justice and the Limits of Diversity: Or Black People and Freedom." In Toward What Justice?: Describing Diverse Dreams of Justice in Education, edited by Eve Tuck and K. Wayne Yang, 85-100. New York: Routledge.

Wan, Amy J. (2014). Producing Good Citizens: Literacy Training in Anxious Times. Pittsburgh: University of Pittsburgh Press.

Welton, Anjalé and Melanie Bertrand. (2019). "Youth Participatory Action Research as Praxis: The Importance of Shared Power among Youth and Adults to Counter Systemic Racism" In Rise Up! Activism as Education, edited by Amalia Dache, Stephen John Quaye, Chris Linder, and Keon M. McGuire, 49-68. East Lansing: Michigan State University Press. 